\title{
Quantitative measures of lambs fed hydrolyzed sugarcane under aerobic and anaerobic conditions
}

\section{Características quantitativas de cordeiros alimentados com cana-de- açúcar hidrolisada em condições aeróbica e anaeróbica}

\author{
Viviane Endo $^{1 *}$; Américo Garcia da Silva Sobrinho ${ }^{2}$; Natália Ludmila Lins Lima ${ }^{1}$; \\ Fabiana Alves de Almeida ${ }^{1}$; Nivea Maria Brancacci Lopes Zeola ${ }^{3}$
}

\begin{abstract}
This study aimed to evaluate the influence of aerobic and anaerobic conditions on hydrolyzed sugarcane, over the in vivo morphological measurements, quantitative traits of carcass and non-carcass components of lambs. Twenty four Ile de France lambs, from 15 to $32 \mathrm{~kg}$ of body weight (BW) were used. Treatments were: in natura sugarcane (IN), sugarcane hydrolyzed using $0.6 \%$ calcium oxide $(\mathrm{CaO})$ under aerobic condition (AER), and sugarcane hydrolyzed using $0.6 \% \mathrm{CaO}$ under anaerobic condition (ANA). Treatments were supplied to animals along with concentrate. Before slaughtering, the lambs were weighed and morphological measurements were taken. After slaughtering, carcasses were evaluated for weight, dressing, non-carcass components, as well as their morphological measurements and weight loss by cooling. A completely randomized design with three treatments and eight replicates was used and the means were compared by Tukey test at $5 \%$ of significance. Lambs fed hydrolyzed sugarcane in aerobic condition had higher leg length $(32.21 \mathrm{~cm})$ and lower rump height $(55.23 \mathrm{~cm})$ in vivo, whereas empty body weight $(24.84 \mathrm{~kg})$ was lower for lambs fed in natura sugarcane. No difference for the other variables was observed. Sugarcane hydrolyzed under aerobic and anaerobic conditions is not an important factor affecting the in vivo, neither the carcass measurements of the animals. The choice between supplying in natura or hydrolyzed sugarcane will depend on an economic analysis.
\end{abstract}

Key words: Hydrolysis, morphology, dressing, Saccharum officinarum

\section{Resumo}

Este estudo teve como objetivo avaliar a influência das condições aeróbicas e anaeróbicas da cana-deaçúcar hidrolisada sobre as medidas morfológicas in vivo, características quantitativas da carcaça, e os não-componentes da carcaça de cordeiros. Foram utilizados 24 cordeiros Ile de France dos 15 aos $32 \mathrm{~kg}$ de peso corporal (PC). Os tratamentos foram: cana-de-açúcar in natura (IN), cana-de-açúcar hidrolisada com $0,6 \%$ de óxido de cálcio $(\mathrm{CaO})$ em condição aeróbica (AER), e cana-de-açúcar hidrolisada com $0,6 \%$ de $\mathrm{CaO}$ em condição anaeróbica (ANA). Os tratamentos foram suplementados com concentrado. Antes do abate, os cordeiros foram pesados e foram obtidas as medidas morfológicas. Após o abate, as carcaças foram pesadas e avaliadas para rendimento, não-componentes, assim como suas medidas morfológicas e perda de peso por resfriamento. Foi utilizado o delineamento inteiramente casualizado com três tratamentos e oito repetições. As médias foram comparadas pelo teste de Tukey a 5\% de significância. Cordeiros alimentados com cana-de-açúcar hidrolisada em condição aeróbica,

\footnotetext{
${ }^{1}$ Discentes da Faculdade de Ciências Agrárias e Veterinárias, FCAV, Universidade Estadual Paulista, UNESP, Jaboticabal, SP, Brasil. E-mail: endo_vica@hotmail.com; nat.ludmila@hotmail.com; faalvesalmeida@yahoo.com.br

2 Prof., Pesquisador da FCAV, UNESP, Jaboticabal, SP, Brasil. E-mail: americo@fcav.unesp.br

${ }^{3}$ Pesquisadora, FCAV, UNESP, FAPESP, Jaboticabal, SP, Brasil. E-mail: nivea.brancacci@ig.com.br

* Author for correspondence
} 
que tiveram maior comprimento de perna $(32.21 \mathrm{~cm})$ e menor altura de garupa $(55.23 \mathrm{~cm})$ in vivo, Enquanto que o peso corporal vazio $(24.84 \mathrm{~kg})$ foi inferior para cordeiros alimentados com cana-deaçúcar in natura. Não foi observada diferença para as demais variáveis. A cana-de-açúcar hidrolisada em condições aeróbica e anaeróbica não é um fator importante em afetar as características in vivo, nem as medidas da carcaça de cordeiros. A escolha entre o fornecimento da cana-de-açúcar in natura ou hidrolisada dependerá de uma análise econômica.

Palavras-chave: Hidrólise, morfologia, rendimento, Saccharum officinarum

\section{Introduction}

Specialized breeds for meat production have greater potential for weight gain in shorter time, and better dressing and finishing degree of the carcasses. The carcass dressing is directly related to the marketing of lambs and interfered with the type of feeding and finishing, gender, age and slaughter weight (RIBEIRO et al., 2001; SILVA SOBRINHO; SAÑUDO; OSÓRIO, 2008).

Some measurements are performed both in vivo in animal and in the carcass as a way to standardize the final product. For example, the conformation and body condition of the living animal will reflect the finishing degree of carcass, as well as indexes of body and carcass compactness will reveal more compact animal carcasses. Cooling loss is another quantitative parameter measured in the carcass. It may be influenced primarily by temperature and its permanency time in the chamber, besides the finishing degree of the carcass (PINHEIRO; SILVA SOBRINHO; ANDRADE, 2009).

Study of non-carcass components assists to add value in sheep-meat production. Its importance is associated with an alternative food source, especially for populations with low purchasing power. The use of non-carcass components for human consumption constitutes a significant source of animal protein. Nutritional value of organs can be compatible or even superior to the beef meat. The organs and viscera have different growth rates over the life of the animal when compared to other parts of the body and may be related to the chemical composition of the food, especially the energy rate, requiring valorizing of the whole animal (LOUVANDINI et al., 2007).
In a feedlot farming system, feed cost is one of the fundamental aspects to the viability or not in meat production (YAMAMOTO, 2006). Therefore, the choice of the feed that will be provided to the animals must account for favorable nutritional and economical aspects for production. There are many advantages of using sugarcane: easily cultivated, high content of energy, and high potential of dry matter production per unit of area, especially when forage is scarce. It has, however, some disadvantages: low crude protein content that requires protein supplementation, and a need for daily cut due to the high concentration of soluble carbohydrates which makes the environment propitious for the development of microorganisms that deteriorate the chopped sugarcane. To overcome the latter disadvantage, alkaline treatment of sugarcane has been promoted using calcium oxide $(\mathrm{CaO})$, which can also improve the nutritive value of sugarcane by increasing the digestibility of fibers (ZEOULA et al., 2006; MORENO et al., 2010; OLIVEIRA, 2010; BERCHIELLI; PIRES; OLIVEIRA, 2011; CARVALHO et al., 2011).

A $\mathrm{pH}$ increase due to the application of $\mathrm{CaO}$ in sugarcane is followed by a gradual $\mathrm{pH}$ decrease due to aerobic exposure of sugarcane. This decrease is linear, but it is not interesting, because the $\mathrm{pH}$ decrease occurs by action of microorganisms. These microorganisms consume the soluble carbohydrates and cause acidification of sugarcane, therefore its aerobic stability decreases (RABELO et al., 2011). With the hydrolysis of sugarcane under anaerobic condition, i.e., with no exposure to oxygen, theoretically, in the course of time, $\mathrm{pH}$ gradually decreases slower than in hydrolysis 
under aerobic exposure, which may result in a less favorable environment for the development of aerobic microorganisms, such as yeasts (ENDO et al., 2014). Therefore, this study aimed to evaluate the influence of aerobic and anaerobic conditions on hydrolyzed sugarcane included as roughage in the diet, over the in vivo morphological measurements, quantitative traits of carcass and the non-carcass components of lambs.

\section{Material and Methods}

The experiment was carried out at São Paulo State University (Unesp) in Jaboticabal, Brazil. Twenty-four Ile de France lambs, uncastrated and weaned at $14 \mathrm{~kg}$ body weight (BW) were used. At $15 \pm 0.221 \mathrm{~kg} \mathrm{BW}$, lambs were identified with numerical marking on the back region. Lambs were housed in individual pens $\left(1.0 \mathrm{~m}^{2}\right)$, with slatted and suspended floor. These facilities were equipped with bunks and waterers installed in covered sheds. Lambs were distributed in a completely randomized design with three treatments and eight replicates: in natura sugarcane + concentrate (IN), sugarcane hydrolyzed using $0.6 \% \mathrm{CaO}$ in aerobic condition + concentrate (AER) and sugarcane hydrolyzed using $0.6 \% \mathrm{CaO}$ in anaerobic condition + concentrate (ANA). Chemical composition of the ingredients is in Table 1. Composition, percentage and chemical analysis of diets are in Table 2.

Table 1. Chemical and crude energy composition of the ingredients of the experimental diets (expressed in DM).

\begin{tabular}{|c|c|c|c|c|c|}
\hline \multirow{3}{*}{ Nutrient } & \multicolumn{3}{|c|}{ Sugarcane } & \multirow{3}{*}{$\begin{array}{c}\text { Soybean } \\
\text { meal }\end{array}$} & \multirow{3}{*}{$\begin{array}{c}\text { Ground } \\
\text { corn }\end{array}$} \\
\hline & \multirow[b]{2}{*}{ in natura } & \multicolumn{2}{|c|}{ Hydrolyzed with $\mathrm{CaO}(0.6 \%)$} & & \\
\hline & & Aerobic & Anaerobic & & \\
\hline Dry matter $(\%)$ & 33.75 & 30.64 & 30.71 & 90.18 & 89.80 \\
\hline Organic matter $(\%)$ & 32.01 & 27.06 & 26.78 & 83.29 & 87.39 \\
\hline Crude protein $(\%)$ & 1.51 & 1.49 & 1.46 & 47.50 & 10.48 \\
\hline Ether extract (\%) & 1.85 & 1.45 & 1.27 & 1.75 & 6.85 \\
\hline Lignin (\%) & 5.63 & 5.19 & 5.53 & 7.75 & 2.51 \\
\hline Neutral detergent fiber $(\%)^{1}$ & 41.09 & 37.54 & 37.67 & 20.89 & 10.11 \\
\hline Acid detergent fiber (\%) & 22.90 & 20.10 & 20.11 & 8.51 & 2.70 \\
\hline Hemicellulose (\%) & 18.19 & 17.44 & 17.56 & 12.38 & 7.41 \\
\hline Cellulose (\%) & 17.27 & 14.91 & 0.76 & 7.60 & 0.19 \\
\hline Total carbohydrates $(\%)^{2}$ & 95.87 & 92.72 & 94.29 & 43.87 & 80.25 \\
\hline Non-fibrous carbohydrates $(\%)^{3}$ & 58.33 & 55.05 & 53.20 & 22.89 & 70.14 \\
\hline Crude energy $\left(\mathrm{Mcal} \mathrm{kg} \mathrm{kg}^{-1}\right)$ & 3.88 & 3.70 & 3.82 & 4.56 & 4.37 \\
\hline
\end{tabular}

${ }^{1}$ Neutral detergent fiber corrected for ash and protein

${ }^{2}$ Total carbohydrates $=100-(\% \mathrm{CP}+\% \mathrm{EE}+\% \mathrm{MM})$

${ }^{3}$ Non-fibrous carbohydrates $=100-(\% \mathrm{NDFap}+\% \mathrm{CP}+\% \mathrm{EE}+\% \mathrm{MM})$.

Source: Elaboration of the authors.

Diets were formulated according to NRC (2007) for lamb weight gain of $250 \mathrm{~g} \mathrm{day}^{-1}$, constituting diets with $22 \% \mathrm{CP}$ and $3.9 \mathrm{Mcal}$ of crude energy (CE) and $2.68 \mathrm{Mcal}$ of metabolize energy (ME) per $\mathrm{kg}$ of dry matter (DM), with roughage:concentrate rate of 50:50.
Lime had a chemical composition of $93.37 \%$ $\mathrm{CaO}, 0.6 \%$ of magnesium oxide $(\mathrm{MgO})$, and $0.1 \%$ phosphorus (P). The IAC 86-2480 was the variety of sugarcane used. A second cut of sugarcane with nine months of growing, non-defoliated and chopped in particle size from 0.8 to $1.0 \mathrm{~cm}$ 
was provided in natura or hydrolyzed under aerobic and anaerobic conditions, depending on the treatment. In natura sugarcane was cut daily and was kept for 2-day ripening, after that, it was chopped in specific equipment and provided to the lambs. Hydrolyzed sugarcane was cut daily, chopped and treated using $0.6 \% \mathrm{CaO}$ per $100 \mathrm{~kg}$ of sugarcane (OLIVEIRA, 2010). A suspension was made by diluting $0.6 \mathrm{~kg}$ of $\mathrm{CaO}$ in 2.0 liters of water. Sugarcane remained under aerobic and anaerobic conditions for 2-day ripening before being provided to the lambs.

Table 2. Ingredients percentage, chemical, bromatological and gross energy composition of the experimental diets (express in dry matter, DM).

\begin{tabular}{|c|c|c|c|}
\hline \multirow{2}{*}{ Percentual composition } & \multicolumn{3}{|c|}{ Treatment } \\
\hline & IN & AER & ANA \\
\hline Sugarcane & 49.93 & 52.69 & 50.99 \\
\hline Urea & 1.27 & 1.20 & 1.21 \\
\hline Ground corn & 8.09 & 7.64 & 7.76 \\
\hline Soybean meal & 37.97 & 35.87 & 36.41 \\
\hline Sodium chloride & 0.33 & 0.31 & 0.31 \\
\hline Limestone & 1.15 & 1.08 & 1.10 \\
\hline Phosphate dicalcium & 0.80 & 0.76 & 0.77 \\
\hline Mineral mixture ${ }^{1}$ & 0.47 & 0.44 & 0.45 \\
\hline \multicolumn{4}{|c|}{ Chemical and bromatological (on DM basis) } \\
\hline Dry matter (\%) & 50.07 & 47.31 & 48.01 \\
\hline Crude protein $(\%)$ & 22.73 & 21.48 & 21.80 \\
\hline Mineral matter $(\%)$ & 6.24 & 6.96 & 7.19 \\
\hline Neutral detergent fiber $(\%)^{2}$ & 27.53 & 28.15 & 29.79 \\
\hline Acid detergent fiber (\%) & 13.17 & 13.56 & 14.92 \\
\hline Hemicellulose (\%) & 14.36 & 14.59 & 14.87 \\
\hline Cellulose (\%) & 7.48 & 7.85 & 9.03 \\
\hline Lignin $(\%)$ & 5.69 & 5.71 & 5.89 \\
\hline Ether extract (\%) & 2.14 & 1.92 & 1.83 \\
\hline Organic matter $(\%)$ & 93.76 & 93.04 & 92.81 \\
\hline Total carbohydrates $(\%)^{3}$ & 68.89 & 68.72 & 69.18 \\
\hline Non-fiber carbohydrates $(\%)^{4}$ & 41.36 & 40.57 & 39.39 \\
\hline Crude energy $\left(\mathrm{Mcal} \mathrm{kg}^{-1}\right)$ & 4.02 & 3.92 & 3.99 \\
\hline
\end{tabular}

$\mathrm{IN}=$ in natura sugarcane + concentrate, $\mathrm{AER}=$ hydrolyzed sugarcane with $0.6 \%$ of $\mathrm{CaO}$ in aerobic condition + concentrate, $\mathrm{ANA}$ $=$ hydrolyzed sugarcane with $0.6 \%$ of $\mathrm{CaO}$ in anaerobic condition + concentrate.

${ }^{1}$ Mineral mixture: zinc 1,600 mg, copper $300 \mathrm{mg}$, manganese 1,500 mg, iron 1,100 mg, cobalt $10 \mathrm{mg}$, iodine $27 \mathrm{mg}$, selenium $22 \mathrm{mg}$ ${ }^{2}$ Neutral detergent fiber corrected for ash and protein

${ }^{3}$ Total carbohydrates $=100-(\% \mathrm{CP}+\% \mathrm{EE}+\% \mathrm{MM})$

${ }^{4}$ Non-fiber carbohydrates $=100-(\%$ NDFap $+\% \mathrm{CP}+\% \mathrm{EE}+\% \mathrm{MM})$.

Source: Elaboration of the authors.

To obtain the hydrolyzed sugarcane, it was chopped and spread on a tarp, forming a stack. Calcium oxide suspension was poured slowly over the sugarcane, and after that, the stack was revolved for complete homogenization to assure that the fibers were hydrolyzed. The stack of sugarcane 
hydrolyzed under aerobic condition remained on the tarp. Whereas, sugarcane hydrolyzed under anaerobic condition was stored in screw-top drums, which avoided the contact of oxygen with the hydrolyzed sugarcane.

When reaching $15 \mathrm{~kg}$ of $\mathrm{BW}$, lambs were treated with anthelmintic and supplemented with vitamins $\mathrm{A}, \mathrm{D}$ and $\mathrm{E}$, and then, confined in individual pens. The animals received a mixed diet in the bunks, allowing 10\% refusals of what was supplied. Diets were delivered twice daily, at 8 and 17 hours. Lambs were weighed weekly to monitor weight gain.

At $32 \mathrm{~kg}$ of BW, lambs were weighed and fasted of solid diet for 16 hours. Before slaughtering, lambs were weighed again to obtain the weight at slaughter (WS) and fasting loss weight (FLW), then they were evaluated in the following morphological measurements: body length (distance in centimeters between neck base, joint and cervicothoracic tail base, first joint intercoccigea), height above (distance between the withers and distal forelimb), rump height (distance between the sacral tuberosity, on the rump, and the distal hind limb), heart girth (measured after the scapula), rump width (maximum width between the trochanters of the femurs) and chest width (distance between the sides of the scapular-humeral joint) (SEARLE; GRAHAM; DONNELLY, 1989; OSÓRIO, 1998; YÁÑEZ et al., 2004). Measurements were obtained with the lambs positioned on a flat and horizontal surface, by the same evaluator in order to minimize errors.

Body condition was evaluated according to Silva Sobrinho (2001), palpation of the dorsal vertebral column through the amount of fat and muscle found in the angle formed by the dorsal and transverse processes, assigning scores from 1 to 5 , in which 1 represents an animal with lower body condition (too skinny), 2 (skinny), 3 (normal), 4 (fat) and 5 (excessively fat).

After the in vivo evaluations, lambs were numbed by electronarcosis with electrical discharge of $250 \mathrm{~V}$ for two seconds, and then slaughtered by section of the jugular veins and carotid arteries. Later, separations and quantifications of the weights of non-carcass components, in relation to body weight at slaughter was made: blood, skin, reproductive tract with bladder, kidney with perirenal fat, liver, spleen, heart, gastrointestinal tract with the esophagus, respiratory tract with trachea and diaphragm, tongue, pancreas, omental (covers the stomach) and mesenteric fat (covers the intestines), head and paws. The gastrointestinal tract was emptied to obtain empty body weight $(\mathrm{EBW}=\mathrm{BWS}$ - gastrointestinal tract - gallbladder contents - contents of the bladder) to determine the true or biological dressing, which is the relationship between hot carcass weight (HCW) and EBW * 100 (SAÑUDO; SIERRA, 1986).

After evisceration, carcasses were weighed, dressing the $\mathrm{HCW}$ to determine the hot carcass dressing $(\mathrm{HCD}=\mathrm{HCW} / \mathrm{WS} * 100)$ and transferred to cold storage at $6^{\circ} \mathrm{C}$ for 24 hours, hanging by gastrocnemius tendons, on appropriate hooks and spaced $17 \mathrm{~cm}$.

After this period, cold carcass weight (CCW) was weighed, calculating the percentage of weight loss by cooling $(\mathrm{WLC}=(\mathrm{HCW}-\mathrm{CCW} / \mathrm{HCW}) *$ $100)$ and commercial dressing $(\mathrm{CD}=(\mathrm{CCW} / \mathrm{WS})$ * 100). Subjectively, conformation was determined according to the methodology of ColomerRocher, Delfa and Sierra (1988), attributing grade 1 (bottom), 2 (fair), 3 (good) 4 (very good), and 5 (excellent). Finishing degree or fat cover was also determined following the same methodology, attributing grade 1 (too skinny), 2 (skinny), 3 (normal), 4 (fat), and 5 (very fat). Then they took up the carcass morphological measures: carcass external length (CEL, distance between the base of the neck, cervical-thoracic joint and base of tail, first joint intercoccigea), carcass internal length (CIL, maximum distance between the front edge of the ischio-pubic and the anterior edge of the first rib at its midpoint), leg length (distance between the greater trochanter and the lateral edge of the tarsal- 
metatarsal joint), hind perimeter (as it involves the trochanters femurs), rump width (maximum width between the trochanters of the femurs), chest circumference (scapula after considering the largest circumference), chest width (maximum width, the greater amplitude of the ribs) and chest depth (distance maximum between the sternum and the back of the palette), according to Osório (1998) and Yamamoto (2006).

With previous determinations, the carcass compactness index $\left.\left(\mathrm{RCC}_{(\mathrm{kg} \mathrm{cm}}{ }^{-1}\right)=\mathrm{CCW} / \mathrm{CIL}\right)$ and leg compactness index ( $\mathrm{LCI}=$ rump width / length of the leg) were calculated. Measurements of length, height and girth were taken with a tape measure, and the measures of width and depth, with a compass, which opening measure was recorded with a ruler.

Experimental design was the completely randomized with three treatments and eight replicates. Data were subjected to analysis of variance by PROC GLM using software SAS (2001), at 5\% significance level. When significant differences were detected, means were tested by Tukey HSD range test at 5\% significance level.

The statistical model used was:

$$
\mathrm{Yij}=\mu+\pi \mathrm{i}+\mathrm{eij},
$$

where Yij is the observed value of the variable studied in animal $\mathrm{j}$, diet $\mathrm{i} ; \mu$ is the general mean common to all observations (constant); $\pi \mathrm{i}$ is the effect of treatment; eij is the random error associated with each observation (measurement errors, uncontrollable factors, differences between experimental units).

\section{Results and Discussion}

Sugarcane is viable because it is a tropical grass and presents a high production of dry matter and energy per unit of area. In this study, the influence of the AER and ANA conditions on the sugarcane hydrolysis regarding morphological parameters in vivo and in the carcass of lambs, as well as dressing of carcass and non-components was assessed.

Table 3 contains the values and coefficients of variation for the morphological measurements in vivo of lambs. No difference was observed in morphological means among treatments, except for rump height, which lambs fed hydrolyzed sugarcane in anaerobic condition $(55.23 \mathrm{~cm})$ had lower rump height than lambs fed in natura sugarcane $(57.98 \mathrm{~cm})$ and hydrolyzed in aerobic condition $(59.31 \mathrm{~cm})$. Means of morphological measurements were: corporal condition of 3.00, body length of $55.20 \mathrm{~cm}$, height above of 57.92 $\mathrm{cm}$, rump width of $20.66 \mathrm{~cm}$, chest width of 20.80 $\mathrm{cm}$, leg length of $51.25 \mathrm{~cm}$ and body compactness index of 0.57 .

The mean of the rump height found for this study was $57.49 \mathrm{~cm}$ (Table 3), corroborating with Moreno et al. (2010) that found $58.55 \mathrm{~cm}$ to assess the in vivo morphological traits and in the carcass of lambs finished in feedlot with sugarcane and corn silage using different roughage:concentrate ratio. The commercial value of an animal to produce meat is not accounted just by its body weight, but along with other measures, such as body length, which provides the body compactness (OSÓRIO; OSÓRIO, 2005). The body compactness index of $0.57 \mathrm{~kg} \mathrm{~cm}^{-1}$ obtained in this study is similar to $0.51 \mathrm{~kg} \mathrm{~cm}^{-1}$ mentioned by Roger et al. (2010) who evaluated in vivo and in the carcass measures of lambs. On body condition, one seeks to estimate muscle:fat ratio, which is linked with the finishing degree of the carcass. The average body condition (3.00) in this study was lower than that found by Moreno et al. (2010) of 3.50 . 
Table 3. Morphological measures in vivo in lambs fed with diets containing in natura or hydrolyzed sugarcane in aerobic and anaerobic conditions.

\begin{tabular}{|c|c|c|c|c|c|c|}
\hline \multirow{2}{*}{ Variable } & \multicolumn{3}{|c|}{ Treatment } & \multirow{2}{*}{ Mean } & \multirow{2}{*}{$\operatorname{Pr}>F$} & \multirow{2}{*}{$\mathrm{CV}(\%)$} \\
\hline & IN & AER & ANA & & & \\
\hline Corporal condition $^{1}$ & 3.00 & 3.00 & 3.00 & 3.00 & ns & 12.97 \\
\hline Body length $(\mathrm{cm})$ & 53.67 & 57.57 & 54.14 & 55.20 & ns & 16.02 \\
\hline Height above $(\mathrm{cm})$ & 58.35 & 58.64 & 56.83 & 57.92 & $\mathrm{~ns}$ & 3.03 \\
\hline Rump height $(\mathrm{cm})$ & $57.98^{\mathrm{a}}$ & $59.31^{\mathrm{a}}$ & $55.23^{\mathrm{b}}$ & 57.48 & * & 3.76 \\
\hline Rump width (cm) & 20.83 & 20.49 & 20.69 & 20.66 & ns & 6.86 \\
\hline Chest width (cm) & 21.18 & 20.26 & 21.01 & 20.80 & $\mathrm{~ns}$ & 4.42 \\
\hline Leg length $(\mathrm{cm})$ & 51.83 & 52.50 & 49.50 & 51.25 & ns & 5.03 \\
\hline Body compactness index $\left(\mathrm{kg} \mathrm{cm}^{-1}\right)$ & 0.59 & 0.53 & 0.59 & 0.57 & ns & 26.38 \\
\hline
\end{tabular}

${ }^{1}$ Scores from 1 to 5 , that means $1=$ too skinny, $2=$ skinny, $3=$ normal, $4=$ fat e $5=$ very fat

$\mathrm{IN}=$ in natura sugarcane + concentrate; $\mathrm{AER}=$ hydrolyzed sugarcane with $0.6 \%$ of $\mathrm{CaO}$ in aerobic condition + concentrate; ANA

$=$ hydrolyzed sugarcane with $0.6 \%$ of $\mathrm{CaO}$ in anaerobic condition + concentrate

Tukey test $(\mathrm{P}<0.05)$. Different letters in rows, shown significant differences among means.

Source: Elaboration of the authors.

Results of carcass morphological There was no difference for treatments in the measurements of lambs finished in feedlot are variables: conformation (3.5), finishing degree shown in Table 4 and difference can be observed (3.0), carcass external length, CEL $(53.13 \mathrm{~cm})$, only for leg length. Lambs fed hydrolyzed carcass internal length, CIL (55.33 cm), rump sugarcane in aerobic condition had greater leg width $(21.96 \mathrm{~cm})$, chest width $(23.99 \mathrm{~cm})$, carcass length $(32.21 \mathrm{~cm})$ than lambs fed hydrolyzed compactness index, CCI $\left(0.23 \mathrm{~kg} \mathrm{~cm}^{-1}\right)$, and leg sugarcane in anaerobic condition $(31.07 \mathrm{~cm})$. compactness index, LCI $(0.41)$.

Table 4. Morphological measures in lambs carcass fed with diets containing in natura or hydrolyzed sugarcane in aerobic and anaerobic conditions.

\begin{tabular}{|c|c|c|c|c|c|c|}
\hline \multirow{2}{*}{ Variable } & \multicolumn{3}{|c|}{ Treatment } & \multirow{2}{*}{ Mean } & \multirow{2}{*}{$\operatorname{Pr}>F$} & \multirow{2}{*}{$\mathrm{CV}(\%)$} \\
\hline & IN & AER & ANA & & & \\
\hline Conformation $^{1}$ & 3.50 & 3.50 & 3.50 & 3.50 & ns & 14.70 \\
\hline Finishing degree $^{2}$ & 3.00 & 3.00 & 3.00 & 3.00 & ns & 10.87 \\
\hline External length $(\mathrm{cm})$ & 53.17 & 53.36 & 52.86 & 53.12 & ns & 3.58 \\
\hline Internal length $(\mathrm{cm})$ & 55.50 & 55.43 & 55.07 & 55.32 & ns & 3.03 \\
\hline Leg length $(\mathrm{cm})$ & $31.75^{\mathrm{ab}}$ & $32.21^{\mathrm{a}}$ & $31.07^{\mathrm{b}}$ & 31.67 & $*$ & 2.10 \\
\hline Rump width (cm) & 22.08 & 22.03 & 21.79 & 21.96 & ns & 4.26 \\
\hline Chest width $(\mathrm{cm})$ & 23.77 & 23.96 & 24.20 & 23.98 & ns & 3.68 \\
\hline Carcass compactness index $\left(\mathrm{kg} \mathrm{cm}^{-1}\right)$ & 0.23 & 0.24 & 0.24 & 0.24 & ns & 3.36 \\
\hline Leg compactness index & 0.41 & 0.41 & 0.41 & 0.41 & ns & 7.45 \\
\hline
\end{tabular}

${ }^{1}$ Score from 1 to 5 , that means $1=$ bottom, $2=$ fair, $3=$ good, $4=$ very good e $5=$ excellent

${ }^{2}$ Score from 1 to 5 , that means $1=$ too skinny, $2=$ skinny, $3=$ normal, $4=$ fat e $5=$ very fat

$\mathrm{IN}=$ in natura sugarcane + concentrate; $\mathrm{AER}=$ hydrolyzed sugarcane with $0.6 \%$ of $\mathrm{CaO}$ in aerobic condition + concentrate; ANA $=$ hydrolyzed sugarcane with $0.6 \%$ of $\mathrm{CaO}$ in anaerobic condition + concentrate

Tukey test $(\mathrm{P}<0.05)$. Different letters in rows, shown significant differences among means

Source: Elaboration of the authors. 
Difference for leg length (Table 4) was not expected, because the lambs were slaughtered with similar ages (153 days) and weights $(32.0 \mathrm{~kg})$. This difference between the means can be explained by the low coefficient of variation $(2.10 \%)$ found for leg length, making it more sensitive to the observation between variation of data.

Values of 3.00 of fat cover, $53.13 \mathrm{~cm}$ of carcass external length, $55.33 \mathrm{~cm}$ of carcass internal length and $23.99 \mathrm{~cm}$ of chest width were found (Table 4). Similarly, when measuring carcass morphological traits of Ile de France lambs finished in feedlot, receiving in natura sugarcane, and slaughtered at $32.0 \mathrm{~kg}$ of BW, Moreno et al. (2010) found $3.00 \mathrm{~cm}$ of fat cover, carcass external length of $53.65 \mathrm{~cm}$, carcass internal length of $56.30 \mathrm{~cm}$ and chest width of $24.12 \mathrm{~cm}$. On the other hand, the results found in this study for leg length $(31.68 \mathrm{~cm})$ and rump width $(21.96 \mathrm{~cm})$ were lower than $35.69 \mathrm{~cm}$ for leg length and $24.05 \mathrm{~cm}$ for rump width (MORENO et al., 2010).

There was no difference for any quantitative traits of lamb carcasses (Table 5). The mean values were: hot carcass weight (HCW) of $13.61 \mathrm{~kg}$, hot carcass dressing (HCD) of $44.88 \%$, cold carcass weight $(\mathrm{CCW})$ of $13.20 \mathrm{~kg}$, commercial dressing (CD) of $43.49 \%$, true dressing (TD) of $53.74 \%$ and loss by cooling (LC) of $3.08 \%$. These values were lower than Mendes et al. (2008) when evaluating parameters of the Santa Ines carcass fed in natura sugarcane and slaughtered at $40.0 \mathrm{~kg}$ of BW (HCW of $20.9 \mathrm{~kg}$, HCD of $47.5 \%$, CCW of $13.20 \mathrm{~kg}$, CD of $46.50 \%$, and LC of $2.1 \%$ ). Murta et al. (2010), when evaluating the quantitative measurement of carcass of lambs fed hydrolyzed sugarcane with $\mathrm{CaO}$ and lambs slaughtered at $30.0 \mathrm{~kg}$ of BW found $\mathrm{HCW}$ of $14.66 \mathrm{~kg}, \mathrm{HCD}$ of $46.62 \%$, CCW of $14.35 \mathrm{~kg}$, CD of $45.45 \%$, and LC of $2.09 \%$.

Table 5. Hot carcass weight, cold carcass weight, hot carcass dressing, commercial dressing and true or biological dressing and loss by cooling of lambs fed with diets containing in natura or hydrolyzed sugarcane in aerobic and anaerobic conditions.

\begin{tabular}{|c|c|c|c|c|c|c|}
\hline \multirow{2}{*}{ Variable } & \multicolumn{3}{|c|}{ Treatment } & \multirow{2}{*}{ Mean } & \multirow{2}{*}{$\operatorname{Pr}>F$} & \multirow{2}{*}{$\mathrm{CV}(\%)$} \\
\hline & IN & AER & ANA & & & \\
\hline Hot carcass weight $(\mathrm{kg})$ & 13.39 & 13.72 & 13.72 & 13.61 & ns & 2.42 \\
\hline Cold carcass weight (kg) & 13.01 & 13.30 & 13.27 & 13.20 & ns & 2.70 \\
\hline Hot carcass dressing $(\%)$ & 44.59 & 45.02 & 45.00 & 44.88 & ns & 3.14 \\
\hline Commercial dressing $(\%)$ & 43.31 & 43.64 & 43.51 & 43.49 & ns & 3.38 \\
\hline True dressing (\%) & 53.91 & 53.56 & 53.77 & 53.74 & ns & 2.27 \\
\hline Loss by cooling (\%) & 2.88 & 3.07 & 3.27 & 3.08 & $\mathrm{~ns}$ & 24.08 \\
\hline
\end{tabular}

$\mathrm{IN}=$ in natura sugarcane + concentrate; $\mathrm{AER}=$ hydrolyzed sugarcane with $0.6 \%$ of $\mathrm{CaO}$ in aerobic condition + concentrate; $\mathrm{ANA}$ $=$ hydrolyzed sugarcane with $0.6 \%$ of $\mathrm{CaO}$ in anaerobic condition + concentrate.

Source: Elaboration of the authors.

Slaughter body and empty body weight, and the non-carcass components dressing of lambs are shown in Table 6. For BWS there was no difference among treatments, ranging from 30.03 to 30.50 $\mathrm{kg}$, whereas for EBW there was difference. Higher EBW was found in lambs fed hydrolyzed sugarcane in aerobic $(25.61 \mathrm{~kg})$ and anaerobic $(25.52 \mathrm{~kg})$ conditions when compared to those fed in natura sugarcane $(24.84 \mathrm{~kg})$. Means for weight loss fasting was $5.63 \%$ content of the gastrointestinal tract was $5.01 \mathrm{~kg}$ and weight gastrointestinal tract was 2.25 $\mathrm{kg}$. 
Table 6. Weights of slaughter body, empty body and the non-carcass components dressing of lambs fed with diets containing in natura or hydrolyzed sugarcane in aerobic and anaerobic conditions.

\begin{tabular}{|c|c|c|c|c|c|c|}
\hline \multirow{2}{*}{ Variable } & \multicolumn{3}{|c|}{ Treatment } & \multirow{2}{*}{ Mean } & \multirow{2}{*}{$\operatorname{Pr}>F$} & \multirow{2}{*}{$\mathrm{CV}(\%)$} \\
\hline & IN & AER & ANA & & & \\
\hline Body weight $(\mathrm{kg})$ & 31.87 & 32.24 & 31.79 & 31.97 & ns & 2.20 \\
\hline Body weight at slaughter $(\mathrm{kg})$ & 30.03 & 30.49 & 30.50 & 30.35 & ns & - \\
\hline Weight loss fasting $(\%)$ & 5.77 & 5.43 & 4.05 & 5.62 & ns & 27.23 \\
\hline Empty body weight (kg) & $24.84^{\mathrm{b}}$ & $25.61^{\mathrm{a}}$ & $25.52^{\mathrm{a}}$ & 25.34 & * & 1.62 \\
\hline Contents of the gastrointestinal tract $(\mathrm{kg})$ & 5.20 & 4.88 & 4.99 & 5.01 & ns & 10.65 \\
\hline Weight gastrointestinal tract $(\mathrm{kg})$ & 2.22 & 2.27 & 2.27 & 2.25 & ns & 8.44 \\
\hline
\end{tabular}

$\mathrm{IN}=$ in natura sugarcane + concentrate; $\mathrm{AER}=$ hydrolyzed sugarcane with $0.6 \%$ of $\mathrm{CaO}$ in aerobic condition + concentrate; $\mathrm{ANA}$ $=$ hydrolyzed sugarcane with $0.6 \%$ of $\mathrm{CaO}$ in anaerobic condition + concentrate.

Tukey test $(\mathrm{P}<0.05)$. Different letters in rows, shown significant differences among means.

Source: Elaboration of the authors.

There was greater empty body weight for lambs fed hydrolyzed sugarcane (in aerobic or anaerobic conditions), but no difference were observed among treatments for gastrointestinal tract contents and weight of gastrointestinal tract. It is known that the empty body weight is obtained by body weight at slaughter less contents of the gastrointestinal tract, the bladder contents and the bile contents. Therefore, it is suggestive infer that the contents of the bladder (urine) or the contents of the gallbladder (bile) varied among treatments in which the lambs were submitted. The bile salts have as main function a detergent action on particles of fat in the feed. This detergent action reduces the surface tension of particles, decreases the fat globules and assists absorption of fatty acids, monoglycerides, cholesterol and other lipids (AIRES, 1999). Table 2 shows the percentage values of the experimental diets and the ether extract content of the diet IN (2.14\%) compared to diets AER (1.92\%) and ANA $(1.83 \%)$ is higher. This variation may have caused a greater production of bile in the lambs fed the diet IN, consequently, have reduced the empty weight. Another possibility is that these significant results for EBW (Table 6) can be explained by the low coefficient of variation $(1.62 \%)$ of this parameter. Thus, the test was more sensitive in the sense of variation among treatments. Moreno et al. (2010) found $27.24 \mathrm{~kg}$ of EBW in lambs fed in natura sugarcane and corn silage, slaughtered at $32.0 \mathrm{~kg}$ of BW, higher than reported in this study $(25.34$ $\mathrm{kg})$.

Skin is the most valuable non-carcass component and can reach 10 to $20 \%$ of the value of animal, followed by the liver, heart, and fat (FRASER; STAMP, 1989). There was no difference among treatments for percentage of non-carcass components (Table 7). Means for skin (9.83\%), gastrointestinal tract $(7.42 \%)$, head $(5.43 \%)$, blood (3.98\%), paws $(2.65 \%)$, respiratory tract with trachea and diaphragm $(2.25 \%)$, liver $(1.76 \%)$, omental + mesenteric fat $(0.99 \%)$, reproductive tract with bladder $(0.76 \%)$, heart $(0.64 \%)$, kidneys with perirenal fat $(0.51 \%)$, tongue $(0.24 \%)$, spleen $(0.16 \%)$, and pancreas $(0.15 \%)$ were found and did not differ among treatments. Evaluating dressing of non-carcass components of Ile de France lambs fed sugarcane associated with sunflower seeds and vitamin E, Lima et al. (2013) found values slightly higher: skin of $12.23 \%$, gastrointestinal tract of $9.35 \%$, head of $6.57 \%$, blood of $4.60 \%$, paws of $3.22 \%$, respiratory tract with trachea of $3.16 \%$, liver of $1.99 \%$, mesenteric and omental fat of $1.01 \%$, reproductive tract with bladder of $0.94 \%$, heart of $0.54 \%$, kidneys with perirenal fat of $0.45 \%$, tongue of $0.31 \%$, spleen of $0.20 \%$, and pancreas of $0.17 \%$. Silva Sobrinho et al. (2003) studied the 
organ production of $1 / 2$ Ile de France $1 / 2$ Ideal lambs, values for dressing of tongue $(0.23 \%)$ and pancreas slaughtered at 30 and $34 \mathrm{~kg}$ of $\mathrm{BW}$ and found $(0.15 \%)$.

Table 7. Dressing of non-carcass components in relation to body weight at slaughter of lambs fed with diets containing in natura or hydrolyzed sugarcane in aerobic and anaerobic conditions.

\begin{tabular}{|c|c|c|c|c|c|c|}
\hline \multirow{2}{*}{ Variable $(\%)$} & \multicolumn{3}{|c|}{ Treatment } & \multirow{2}{*}{ Mean } & \multirow{2}{*}{$\operatorname{Pr}>F$} & \multirow{2}{*}{$\mathrm{CV}(\%)$} \\
\hline & IN & AER & ANA & & & \\
\hline Gastrointestinal tract & 7.33 & 7.45 & 7.43 & 7.42 & ns & 8.68 \\
\hline Blood & 3.80 & 4.31 & 3.86 & 3.98 & ns & 13.03 \\
\hline Skin & 9.62 & 9.98 & 9.89 & 9.83 & ns & 9.72 \\
\hline Reproductive tract with bladder & 0.72 & 0.79 & 0.78 & 0.76 & ns & 26.54 \\
\hline Kidneys with perirenal fat & 0.51 & 0.49 & 0.55 & 0.51 & ns & 10.39 \\
\hline Spleen & 0.16 & 0.16 & 0.16 & 0.16 & ns & 12.99 \\
\hline Liver & 1.73 & 1.71 & 1.84 & 1.76 & ns & 10.45 \\
\hline Heart & 0.70 & 0.62 & 0.63 & 0.64 & ns & 10.83 \\
\hline Respiratory tract with trachea and diaphragm & 2.44 & 2.28 & 2.08 & 2.25 & ns & 14.06 \\
\hline Tongue & 0.26 & 0.24 & 0.22 & 0.24 & ns & 15.58 \\
\hline Pancreas & 0.14 & 0.17 & 0.16 & 0.15 & ns & 23.06 \\
\hline Omental + mesenteric fat & 1.07 & 0.93 & 1.01 & 0.99 & ns & 10.73 \\
\hline Head & 5.35 & 5.55 & 5.39 & 5.43 & ns & 6.53 \\
\hline Paws & 2.70 & 2.66 & 2.59 & 2.65 & ns & 5.91 \\
\hline Dressing of the non-carcass components & 36.47 & 37.34 & 36.59 & 36.80 & ns & 3.40 \\
\hline
\end{tabular}

$\mathrm{IN}=$ in natura sugarcane + concentrate; $\mathrm{AER}=$ hydrolyzed sugarcane with $0.6 \%$ of $\mathrm{CaO}$ in aerobic condition + concentrate; $\mathrm{ANA}$ $=$ hydrolyzed sugarcane with $0.6 \%$ of $\mathrm{CaO}$ in anaerobic condition + concentrate.

Source: Elaboration of the authors.

\section{Conclusion}

Sugarcane hydrolyzed under aerobic and anaerobic conditions is not an important factor affecting the in vivo, neither the carcass measurements of the animals. The choice between supplying in natura or hydrolyzed sugarcane will depend on an economic analysis.

\section{Acknowlegment}

The authors acknowledge the Faculdade de Ciências Agrárias e Veterinárias, Unesp/Jaboticabal, for the opportunity to develop the experimental work.

The first author benefit from a grant from the
Conselho Nacional de Desenvolvimento Científico e Tecnológico (CNPq).

\section{Ethics committee and biosafety}

This research is in accordance with the Ethical Principles in Animal Experimentation, and was approved by Committee of the Use of Animals, protocol number 011855/12.

\section{References}

AIRES, M. Fisiologia. 2. ed. Rio de Janeiro: Guanabara, 1999. $934 \mathrm{p}$.

BERCHIELLI, T. T.; PIRES, A. V.; OLIVEIRA, S. G. Nutrição de ruminantes. 2. ed. Jaboticabal: Funep, 2011. $616 \mathrm{p}$. 
CARVALHO, G. G. P.; GARCIA, R.; PIRES, A. J. V.; DETMANN, E.; SILVA, R. R.; PEREIRA, M. L. A.; SANTOS, A. B.; PEREIRA, T. C. J. Metabolismo de nitrogênio em novilhas alimentadas com dietas contendo cana-de-açúcar tratado com óxido de cálcio. Revista Brasileira de Zootecnia, Viçosa, MG, v. 40, n. 3, p. 622629, 2011.

COLOMER-ROCHER, F.; DELFA, R.; SIERRA, I. Método normalizado para el estudio de los caracteres cuantitativos y cualitativos de las canales, según los sistemas de produccíon. In: . Método normalizado para el estudio de los caracteres cuantitativos $y$ cualitativos de las canales caprinas y ovinas. INIA: Madrid, 1988. p. 19-41.

ENDO, V.; SILVA SOBRINHO, A. G.; LIMA, N. L. L.; ALMEIDA, F. A.; ZEOLA, N. M. B. L. Evaluation of performance and nutrient intake of lambs fed sugarcane hydrolyzed under different conditions. Revista Semina: Ciências Agrárias, Londrina, v. 35, n. 3, p. 1515-1522, 2014.

FRASER, A.; STAMP, J. T. Ganado ovino: producción y enfermedades. Madri: Mundi-Prensa, 1989. 358 p.

LIMA, N. L. L.; SILVA SOBRINHO, A. G.; ALMEIDA, F. A.; ENDO, V.; ZEOLA, N. M. B. L.; ALMEIDA, A. K.; SAMPAIO, A. A. M. Quantitative and qualitative characteristics of the non-carcass components and the meat of lambs fed sunflower seeds and vitamin E. Revista Brasileira de Zootecnia, Viçosa, MG, v. 42, n. 1, p. 5160, 2013.

LOUVANDINI, H.; NUNES, G. A.; GARCIA, J. A. S.; McMANUS, C.; COSTA, D. M.; ARAÚJO, S. C. Desempenho, características de carcaça e constituintes corporais de ovinos Santa Inês alimentados com farelo de girassol em substituição ao farelo de soja na dieta. Revista Brasileira de Zootecnia, Viçosa, MG, v. 36, n. 3, p. 603-609, 2007.

MENDES, C. Q.; SUSIN, I.; PIRES, A. V.; NUSSIO, L. G.; ARAUJO, R. C.; RIBEIRO, M. F. Desempenho, parâmetros da carcaça e comportamento ingestivo de cordeiros alimentados com cana-de-açúcar ensilada ou in natura. Arquivo Brasileiro de Medicina Veterinária e Zootecnia, Belo Horizonte, v. 60, n. 3, p. 733-740, 2008.

MORENO, G. M. B.; SILVA SOBRINHO, A. G.; LEÃO, A. G.; OLIVEIRA, R. V.; YOKOO, M. J. I.; SOUSA JUNIOR, S. C.; PEREZ, H. L. Características morfológicas in vivo e da carcaça de cordeiros terminados em confinamento e suas correlações. Revista Brasileira de Saúde e Produção Animal, Salvador, v. 11, n. 3, p. 888-902, 2010.
MURTA, R. M.; CHAVES, M. A.; PIRES, A. J. V.; VELOSO, C. M. Bagaço de cana-de-açúcar hidrolisado com óxido de cálcio na alimentação de ovinos confinados. In: XIMENES, L. J. F.; MARTINS, G. A.; MORAIS, O. R. Ciência e tecnologia na pecuária de caprinos e ovinos. Fortaleza: Ed. Banco do Nordeste do Brasil, 2010. p. 153-176.

NATIONAL RESEARCH COUNCIL - NRC. Nutrient requirement of small ruminants: sheep, goats, cervids, and new world camelids. $6^{\text {th }}$ ed. Washington, DC: National Academy Press, 2007. 384 p.

OLIVEIRA, M. D. S. Cana-de-açúcar hidrolisada na alimentação de bovinos. Jaboticabal: Funep, 2010. 115 p.

OSÓRIO, J. C. S. Métodos para avaliação da produção de carne ovina: in vivo, na carcaça e na carne. Pelotas: UFPEL, 1998. 107 p.

OSÓRIO, J. C. S.; OSÓRIO, M. T. M. Produção de carne ovina: técnicas de avaliação in vivo e na carcaça. 2. ed. Pelotas: Universitária, 2005. 78 p.

PINHEIRO, R. S. B.; SILVA SOBRINHO, A. G.; ANDRADE, E. N. Características quantitativas da carcaça de ovinos de diferentes categorias. Revista Brasileira de Saúde e Produção Animal, Salvador, v. 10, n. 4, p. 939-948, 2009.

RABELO, C. H. S.; REZENDE, A. V.; RABELO, F. H. S.; NOGUEIRA, D. A.; ELIAS, R. F.; FARIA JÚNIOR, D. C. N. A. Estabilidade aeróbia de cana-de-açúcar in natura hidrolisada com cal virgem. Ciência Animal Brasileira, Goiânia, v. 12, n. 2, p. 257-265, abr./jun. 2011.

RIBEIRO, E. L. A.; ROCHA, M. A.; MIZUBUTI, I. Y.; SILVA, L. D. F.; RIBEIRO, H. J. S. S.; MORI, R. M. Carcaça de borregos Ile de de France inteiros ou castrados e Hampshire Down castrados abatidos aos doze meses de idade. Revista Ciência Rural, Santa Maria, v. 31, n. 3, p. 479-482, 2001

ROGER, M. G. E.; OSÓRIO, J. C. S.; OSÓRIO, M. T. M.; GILSON, M.; OLIVEIRA, M. M.; WIEGAND, M.; VILANOVA, M. S.; CORREA, F.; JARDIM, R. D. Avaliação in vivo e da carcaça e fatores determinantes para o entendimento da cadeia da carne ovina. Revista Brasileira de Agrociência, Pelotas, v. 16, n. 1-4, p. 101108, 2010.

SAÑUDO, C.; SIERRA, I. Calidad de la canal en la especie ovina. In: BUXADÉ, C. Ovino. Barcelona: Ed. Exclusivas ONE, 1986. p. 127-153.

SEARLE, T. W.; GRAHAM, N. M.; DONNELLY, J. B. Change of skeletal dimensions during growth in sheep: the effect of nutrition. Journal of Agricultural Science, Cambridge, v. 112, n. 3, p. 321-327, 1989. 
SILVA SOBRINHO, A. G. Criação de ovinos. YÁÑEZ, E. A.; RESENDE, K. T.; FERREIRA, A. Jaboticabal: Funep, 2001. 302 p.

C. D.; MEDEIROS, A. N.; SILVA SOBRINHO, A.

SILVA SOBRINHO, A. G.; SAÑUDO, C.; OSÓRIO, J. C. S. Produção de carne ovina. Jaboticabal: Funep, 2008. $228 \mathrm{p}$.

SILVA SOBRINHO, A. G.; GASTALDI, K. A.; GARCIA, C. A.; MACHADO, M. R. F. Diferentes dietas e pesos ao abate na produção de órgãos de cordeiros. Revista Brasileira de Zootecnia, Viçosa, MG, v. 32, n. 6, p. 1792-1799, 2003.

STATISTICAL ANALYSIS SYSTEM INSTITUTE - SAS. Institute system for information. Version 6. 11, Carry: SAS Inst., 2001. Disquete 3. 5'.

G.; PEREIRA FILHO, J. M.; TEIXEIRA, I. A. M. A.; ARTONI, S. M. B. Utilização de medidas biométricas para predizer características da carcaça de cabritos Saanen. Revista Brasileira de Zootecnia, Viçosa, MG, v. 33, n. 6, p. 1564-1572, 2004.

ZEOULA, L. M.; FERELI, F.; PRADO, I. N.; GERON, L. J. V.; CALDAS NETO, S. F.; PRADO, O. P. P.; MAEDA, E. M. Digestibilidade e balanço de nitrogênio de rações com diferentes teores de proteína degradável no rúmen e milho moído como fonte de amido em ovinos. Revista Brasileira de Zootecnia, Viçosa, MG, v. 35, n. 5, p. 21792186, 2006.

YAMAMOTO, S. M. Desempenho e características da carcaça e da carne de cordeiros terminados em confinamento com dietas contendo silagens de resíduos de peixes. 2006. Tese (Doutorado em Zootecnia) - Faculdade de Ciências Agrárias e Veterinárias, Universidade Estadual Paulista, Jaboticabal. 